\title{
Studies on Reproductive Performance of Red Kandhari Cattle in their Breeding Tract of Maharashtra, India
}

\author{
D. V. Bainwad*, B. M. Thombre and S. G. Narwade \\ Department of Animal Husbandry and Dairy Science, Vasantrao Naik Marathwada Krishi \\ Vidyapeeth, College of Agriculture, Parbhani- 431 402, India \\ *Corresponding author
}

\begin{abstract}
A B S T R A C T
Red Kandhari is one of the important breed of Marathwada region of Maharashtra State. This breed is known as Lal Kandhari. In the present investigation the reproductive performance of Red Kandhari cattle at various stages of growth were studied at different locations in the breeding tract. The idea behind the collection of data in breeding tract of Red Kandhari cattle from the farmers and breeders herd of Red Kandhari rather than on the organized farm to obtain the real picture of reproductive performance of breed in the breeding tract. The reproductive traits often help in judging the economic value of the animal. The overall least square means for age at puberty (AP) of Red Kandhari cattle was recorded as $883.16 \pm 0.83$ days. The effect of block and season were found highly significant on AP whereas, the effect of colour was found non-significant. The overall least square means for age at first estrus (AFE) of Red Kandhari cattle was recorded as $1236.96 \pm 1.67$ days. The effect of block and season were found highly significant on AFE whereas, the effect of colour was found non-significant. The overall least square means for age at first calving (AFC) of Red Kandhari cattle was recorded as $1529.61 \pm 1.71$ days. The effect of season was found highly significant on AFC whereas, the effect of block and colour were found non-significant. The overall least square means for service period (SP) of Red Kandhari cattle was recorded as $139.92 \pm 0.66$ days. The effect of block and season were found highly significant on SP whereas, the effect of colour was found nonsignificant. The overall least square means for gestation period (GP) of Red Kandhari cattle was recorded as $283.49 \pm 0.23$ days. The effect of block, season and colour were found non-significant on GP. The improvement in reproductive characteristics of indigenous breeds has become essential to make the economically viable dairy animals.
\end{abstract}

\section{Introduction}

Dairying has become an important secondary source of income for millions of rural families and has assumed the most important role in providing employment and income generating opportunities particularly for marginal and women farmers. The livestock sector alone contributes nearly $25.6 \%$ of value of output at current prices of total value of output in Agriculture, Fishing and Forestry sector. The overall contribution of livestock sector in total GDP is nearly $4.11 \%$ at current prices during 2012-13. India has 190.9 million cattle, 108.7 
million buffaloes, 135.2 million goats and 65.06 million sheep population. The total Bovine population is 299.9 million in 2012 which shows a decline of $1.57 \%$ over previous census (Livestock Census, 2012). Red Kandhari is one of the important breed of Marathwada region of Maharashtra State. The Red Kandhari germplasm has very old and rich historical background. It is said that the breeding of cattle was taken up by the Royal dynasty of king Somadeorai as far back as fourth century A. D. The cattle breed having red colour naturally acquires the name as Red Kandhari as it is sure that the breed would have been named by Raja Somadeorai in memory of his father as Raja Kanhar now misnomered as Red Kandhari (Chauhan et al., 2008). The reproductive characteristics like reproductive characteristics like $\mathrm{AP}, \mathrm{AFE}$, AFC, SP, GP and ICP were taken into consideration for present study. The Red Kandhari breed is reared mainly for draught purpose. Animals are medium in size, strong, compact and good looking. Body colour is dull red to almost dark brown. Cows are low milk producers and bullocks of the breed are preferred over the Deoni breed for better draught ability and smaller size (Pundir and Singh, 2008). Therefore, the present study has been conducted to study the reproductive characteristics, colour pattern effect on various characteristics, effect of season on lactation milk yield and block effect on various characteristics.

\section{Materials and Methods}

\section{Selection of Cattle}

The data on reproductive traits of $597 \mathrm{Red}$ Kandhari cattle was collected by actual interview with the livestock owners with the help of model questionnaire at different villages as mentioned below. From each tehsils on an average 66 cattle / individuals was chosen randomly for present study. The data on reproductive characteristics i.e. AP, AFE, AFC, SP, GP and ICP was collected by actual interview with the livestock owners with the help of model questionnaire. The collected data was classified as per colour pattern (viz., Dark Red, Brick Red followed by Black Shades on NST i.e. Neck, Shoulder and Thigh) and as per seasons as $\mathrm{S}_{1}$ - Premonsoon (March - May), $S_{2}-$ Monsoon (June - September), $S_{3}$ - Post-monsoon (October November) and $\mathrm{S}_{4}$ - Summer (December February). The data on productive traits were collected from different districts of Marathwada region as mentioned in Table 1.

\section{Reproductive characteristics}

The analysis of data will be done by method of Least Square Technique as outlined by Harvey (1990). The following mathematical model will be employed to analyze the data.

$\mathrm{Y}_{\mathrm{ijklm}}=\mu+\mathrm{B}_{\mathrm{i}}+\mathrm{C}_{\mathrm{j}}+\mathrm{S}_{\mathrm{k}}+\mathrm{O}_{\mathrm{l}}+\mathrm{e}_{\mathrm{ijklm}}$

Where,

$\mathrm{Y}_{\mathrm{ijklm}}=$ is the record of $\mathrm{m}^{\text {th }}$ Red Kandhari individual in $i^{\text {th }}$ block, $j^{\text {th }}$ colour, $k^{\text {th }}$ season and $1^{\text {th }}$ off-type.

$\mu=$ is the population mean common to all the observations.

$B_{i}=$ is the effect of $i^{\text {th }}$ block of individual.

$\mathrm{C}_{\mathrm{j}}=$ is the effect of ${ }_{\mathrm{j}}^{\text {th }}$ colour of individual.

$\mathrm{S}_{\mathrm{k}}=$ is the effect of ${ }_{\mathrm{k}}$ th season of individual.

$\mathrm{O}_{1}=$ is the effect of ${ }_{1}^{\text {th }}$ off-type of individual.

$\mathrm{e}_{\mathrm{ijklm}}=$ is the random error assumed to be NID $\left(0, \delta^{2}, \mathrm{e}\right)$

The significant effect will be further analyzed to have all pair wise comparison by Duncan's Multiple Range Test (DMRT) as modified by Kramar (1957). 


\section{Results and Discussion}

\section{Reproductive characteristics}

\section{Age at puberty (AP)}

It was observed from Table 2 that the overall least square means for AP of Red Kandhari cattle was recorded as $883.16 \pm 0.83$ days. Higher days AP was reported by Vedpathak et al., (2006) as $1280.50 \pm 0.73$ days in Red Kandhari cattle and Azizunnesa et al., (2010) as $2.68 \pm 1.71$ years in Red Chittagong cattle, respectively.

\section{Block effect on AP}

The difference observed in the LSMs for AP of Red Kandhari cattle was highly significant due to block effect. The LSM for AP of Red Kandhari cattle in block $\mathrm{D}_{1}, \mathrm{D}_{2}, \mathrm{D}_{3}, \mathrm{D}_{4}$, and $\mathrm{D}_{5}$ were $885.63 \pm 1.35,878.82 \pm 1.38,878.04$ $\pm 1.26,886.53 \pm 1.54$ and $886.78 \pm 2.43$ days, respectively. The DMRT revealed that Red Kandhari cattle maintained at $\mathrm{D}_{5}$ block had highly significant higher AP over other blocks.

\section{Colour pattern effect on AP}

The differences observed in the LSMs for AP of Red Kandhari cattle were non-significant due to colour pattern effect. The LSM for AP of Red Kandhari cattle for colour pattern $\mathrm{C}_{1}$ and $\mathrm{C}_{2}$ were $883.04 \pm 1.01$ and $883.28 \pm 1.08$ days, respectively.

\section{Season effect on Age at puberty}

The differences observed in the LSMs for AP of Red Kandhari cattle were highly significant due to season effect. The LSM for AP of Red Kandhari cattle for season $\mathrm{S}_{1}, \mathrm{~S}_{2}, \mathrm{~S}_{3}$ and $\mathrm{S}_{4}$ were $878.48 \pm 2.01,891.97 \pm 1.89,883.81 \pm$ 1.09 and $878.37 \pm 1.03$ days, respectively. The DMRT revealed that Red Kandhari cattle maintained in $\mathrm{S}_{2}$ season had highly significant higher AP over other seasons.

\section{Age at first estrus (AFE)}

It was observed from Table 3 that the overall least square means for AFE of Red Kandhari cattle was recorded as $1236.96 \pm 1.67$ days. Higher days AFE was reported by Kulkarni et al., (2013) as $41.70 \pm 0.20$ months in Kathani cattle of Vidarbha region of Maharashtra and lower days AFE was reported by Singh et al., (2002) as $35.60 \pm 0.53$ months in Deoni cattle.

\section{Block effect on Age at first estrus}

The difference observed in the LSMs for AFE of Red Kandhari cattle was highly significant due to block effect. The LSM for AFE of Red Kandhari cattle in block $\mathrm{D}_{1}, \mathrm{D}_{2}, \mathrm{D}_{3}, \mathrm{D}_{4}$, and $\mathrm{D}_{5}$ were $1238.51 \pm 2.72,1238.61 \pm 2.77$, $1244.58 \pm 2.53,1235.41 \pm 3.09$ and 1227.71 \pm 4.89 days, respectively. The DMRT revealed that Red Kandhari cattle maintained at $\mathrm{D}_{3}$ block had highly significant higher AFE over other blocks.

\section{Colour pattern effect on Age at first estrus}

The differences observed in the LSMs for AFE of Red Kandhari cattle were nonsignificant due to colour pattern effect. The LSM for AFE of Red Kandhari cattle for colour pattern $\mathrm{C}_{1}$ and $\mathrm{C}_{2}$ were $1237.69 \pm 2.03$ and $1236.24 \pm 2.16$ days, respectively.

\section{Season effect on Age at first estrus}

The differences observed in the LSMs for AFE of Red Kandhari cattle were highly significant due to season effect. The LSM for AFE of Red Kandhari cattle for season $S_{1}, S_{2}$, $S_{3}$ and $S_{4}$ were $1256.59 \pm 4.04,1243.33 \pm$ $3.80,1210.19 \pm 2.19$ and $1237.75 \pm 2.08$ days, respectively. The DMRT revealed that 
Red Kandhari cattle maintained in $\mathrm{S}_{1}$ season had highly significant higher AFE over other seasons.

\section{Age at first calving (AFC)}

It was observed from Table 4 that the overall least square means for AFC of Red Kandhari cattle was recorded as $1529.61 \pm 1.71$ days. Higher days age at first calving was reported by Gokhale (2013) as $52.93 \pm 0.23$ months in Dangi cattle, Kulkarni et al., (2013) as 53.53 \pm 0.20 months in Kathani cattle of Vidarbha region in Maharashtra and Bhutkar (2014) as 1659.15 35.77 days in Deoni cattle at CCBP, Parbahni, respectively and lower days AFC was reported by Pundir and Singh (2008) as 39.47 months in Red Kandhari cattle.

\section{Block effect on AFC}

The difference observed in the LSMs for AFC of Red Kandhari cattle was non- significant due to block effect. The LSM for AFC of Red Kandhari cattle in block $\mathrm{D}_{1}, \mathrm{D}_{2}, \mathrm{D}_{3}, \mathrm{D}_{4}$, and
$\mathrm{D}_{5}$ were $1533.43 \pm 2.77,1530.72 \pm 2.82$, $1528.31 \pm 2.58,1531.56 \pm 3.16$ and 1524.06 \pm 4.98 days, respectively.

\section{Colour pattern effect on AFC}

The differences observed in the LSMs for AFC of Red Kandhari cattle were nonsignificant due to colour pattern effect. The LSM for AFC of Red Kandhari cattle for colour pattern $C_{1}$ and $C_{2}$ were $1528.86 \pm 2.07$ and $1530.37 \pm 2.20$ days, respectively.

\section{Season effect on AFC}

The differences observed in the LSMs for AFC of Red Kandhari cattle were highly significant due to season effect. The LSM for AFC of Red Kandhari cattle for season $S_{1}, S_{2}$, $\mathrm{S}_{3}$ and $\mathrm{S}_{4}$ were $1525.78 \pm 4.12,1553.08 \pm$ $3.88,1510.28 \pm 2.23$ and $1529.32 \pm 2.12$ days, respectively. The DMRT revealed that Red Kandhari cattle maintained in $\mathrm{S}_{2}$ season had highly significant higher AFC over other seasons.

Table.1 List of villages randomly selected for collection of data

\begin{tabular}{|c|c|c|c|}
\hline Sr. No. & $\begin{array}{l}\text { Name of the } \\
\text { District }\end{array}$ & $\begin{array}{l}\text { Name of the } \\
\text { Tehsils }\end{array}$ & Name of the Villages \\
\hline \multirow[t]{2}{*}{1.} & \multirow[t]{2}{*}{ Nanded $\left(D_{1}\right)$} & Kandhar & $\begin{array}{l}\text { Bori (Khu.), Umaraj, Jambhulwadi, Dagadsangavi, } \\
\text { Ghodaj }\end{array}$ \\
\hline & & Loha & $\begin{array}{c}\text { Dhanora (Makta), Subhashnagar, Chitali, Malakoli, } \\
\text { Malegaon }\end{array}$ \\
\hline \multirow[t]{2}{*}{2.} & \multirow[t]{2}{*}{ Latur $\left(\mathrm{D}_{2}\right)$} & Ahmedpur & $\begin{array}{c}\text { Sangavi (Su.), Sunegaon (Sa.), Babaldara, Hippalgaon, } \\
\text { Sawargaon (Thot) }\end{array}$ \\
\hline & & Jalkot & Kunki, Wanjarwada, Hawarga, Jirga, Jagalpur \\
\hline \multirow[t]{2}{*}{3.} & \multirow[t]{2}{*}{ Parbhani $\left(\mathrm{D}_{3}\right)$} & Palam & Kerwadi, Shirpur, Sayal, Kapsi, Pethshivani \\
\hline & & Gangakhed & $\begin{array}{l}\text { Dhavalkewadi, Kaudgaon, Malewadi, Maradasgaon, } \\
\text { Naralad }\end{array}$ \\
\hline \multirow[t]{2}{*}{4.} & \multirow[t]{2}{*}{ Hingoli $\left(\mathrm{D}_{4}\right)$} & Vasmat & Aaral, Darephal, Bori, Aadgaon, Kalamba \\
\hline & & Aundha & Barashiv, Ranjala, Purjal, Sirla, Aajarsonda \\
\hline 5. & Beed $\left(D_{5}\right)$ & Parli & Tokwadi, Sangam, Waghbet, Belamba, Injegaon \\
\hline
\end{tabular}


Table.2 Least squares means for AP as affected by block and colour pattern in Red Kandhari cows

\begin{tabular}{|c|c|c|c|}
\hline Sources & Code & N & Mean AP(Days) \pm SE \\
\hline Population mean & $\mu$ & 597 & $883.16 \pm 0.83$ \\
\hline & \multicolumn{3}{|c|}{ District } \\
\hline Nanded & $\mathrm{D}_{1}$ & 149 & $885.63^{\mathrm{a}} \pm 1.35$ \\
\hline Latur & $\mathrm{D}_{2}$ & 138 & $878.82^{\mathrm{b}} \pm 1.38$ \\
\hline Parbhani & $\mathrm{D}_{3}$ & 164 & $878.04^{\mathrm{b}} \pm 1.26$ \\
\hline Hingoli & $\mathrm{D}_{4}$ & 106 & $886.53^{\mathrm{c}} \pm 1.54$ \\
\hline Beed & $\mathrm{D}_{5}$ & 40 & $886.78^{\mathrm{c}} \pm 2.43$ \\
\hline & & Colour & \\
\hline Dark Red & $\mathrm{C}_{1}$ & 336 & $883.04 \pm 1.01$ \\
\hline Brick Red & $\mathrm{C}_{2}$ & 261 & $883.28 \pm 1.08$ \\
\hline & & Season & \\
\hline Pre-monsoon & $\mathrm{S}_{1}$ & 58 & $878.48^{\mathrm{a}} \pm 2.01$ \\
\hline Monsoon & $\mathrm{S}_{2}$ & 67 & $891.97^{\mathrm{b}} \pm 1.89$ \\
\hline Post-monsoon & $\mathrm{S}_{3}$ & 231 & $883.81^{\mathrm{bc}} \pm 1.09$ \\
\hline Summer & $\mathrm{S}_{4}$ & 241 & $878.37^{\mathrm{c}} \pm 1.03$ \\
\hline
\end{tabular}

Note: Means connected by same superscripts do not differ significantly

Table.3 Least squares means for AFE as affected by block and colour pattern in Red Kandhari cows

\begin{tabular}{|l|l|l|l|}
\hline Sources & Code & N & Mean AFE (Days) \pm SE \\
\hline Population mean & $\mu$ & 597 & $1236.96 \pm 1.67$ \\
\hline District & \multicolumn{3}{|l|}{} \\
\hline Nanded & $\mathrm{D}_{1}$ & 149 & $1238.51^{\mathrm{a}} \pm 2.72$ \\
\hline Latur & $\mathrm{D}_{2}$ & 138 & $1238.61^{\mathrm{a}} \pm 2.77$ \\
\hline Parbhani & $\mathrm{D}_{3}$ & 164 & $1244.58 \mathrm{a} \pm 2.53$ \\
\hline Hingoli & $\mathrm{D}_{4}$ & 106 & $1235.41^{\mathrm{b}} \pm 3.09$ \\
\hline Beed & $\mathrm{D}_{5}$ & 40 & $1227.71^{\mathrm{b}} \pm 4.89$ \\
\hline Colour & & & \\
\hline Dark Red & $\mathrm{C}_{1}$ & 336 & $1237.69 \pm 2.03$ \\
\hline Brick Red & $\mathrm{C}_{2}$ & 261 & $1236.24 \pm 2.16$ \\
\hline Season & & & \\
\hline Pre-monsoon & $\mathrm{S}_{1}$ & 58 & $1256.59^{\mathrm{a}} \pm 4.04$ \\
\hline Monsoon & $\mathrm{S}_{2}$ & 67 & $1243.33^{\mathrm{b}} \pm 3.80$ \\
\hline Post-monsoon & $\mathrm{S}_{3}$ & 231 & $1210.19^{\mathrm{bc}} \pm 2.19$ \\
\hline Summer & $\mathrm{S}_{4}$ & 241 & $1237.75^{\mathrm{b}} \pm 2.08$ \\
\hline
\end{tabular}

Note: Means connected by same superscripts do not differ significantly 
Table.4 Least squares means for AFC as affected by block and colour pattern in Red Kandhari cows

\begin{tabular}{|l|l|l|l|}
\hline $\begin{array}{l}\text { Sources } \\
\text { Population } \\
\text { mean }\end{array}$ & $\mu$ & 597 & $1529.61 \pm 1.71$ \\
\hline $\begin{array}{l}\text { District } \\
\text { Nanded }\end{array}$ & $\mathrm{D}_{1}$ & 149 & $1533.43 \pm 2.77$ \\
\hline Latur & $\mathrm{D}_{2}$ & 138 & $1530.72 \pm 2.82$ \\
\hline Parbhani & $\mathrm{D}_{3}$ & 164 & $1528.31 \pm 2.58$ \\
\hline Hingoli & $\mathrm{D}_{4}$ & 106 & $1531.56 \pm 3.16$ \\
\hline Beed & $\mathrm{D}_{5}$ & 40 & $1524.06 \pm 4.98$ \\
\hline Colour & & & \\
\hline Dark Red & $\mathrm{C}_{1}$ & 336 & $1528.86 \pm 2.07$ \\
\hline Brick Red & $\mathrm{C}_{2}$ & 261 & $1530.37 \pm 2.20$ \\
\hline Season & & & \\
\hline Pre-monsoon & $\mathrm{S}_{1}$ & 58 & $1525.78^{\mathrm{a}} \pm 4.12$ \\
\hline Monsoon & $\mathrm{S}_{2}$ & 67 & $1553.08^{\mathrm{b}} \pm 3.88$ \\
\hline Post-monsoon & $\mathrm{S}_{3}$ & 231 & $1510.28^{\mathrm{bc}} \pm 2.23$ \\
\hline Summer & $\mathrm{S}_{4}$ & 241 & $1529.32^{\mathrm{c}} \pm 2.12$ \\
\hline
\end{tabular}

Note: Means connected by same superscripts do not differ significantly

Table.5 Least squares means for SP as affected by block and colour pattern in Red Kandhari cows

\begin{tabular}{|l|l|l|l|}
\hline $\begin{array}{l}\text { Sources } \\
\text { Population } \\
\text { mean }\end{array}$ & Code & $\mathbf{N}$ & Mean SP (Days) \pm SE \\
\hline $\begin{array}{l}\text { District } \\
\text { Nanded }\end{array}$ & $\mathrm{D}_{1}$ & 149 & $139.92 \pm 0.66$ \\
\hline Latur & $\mathrm{D}_{2}$ & 138 & $140.22^{\mathrm{b}} \pm 1.07$ \\
\hline Parbhani & $\mathrm{D}_{3}$ & 164 & $145.69^{\mathrm{bc}} \pm 1.00$ \\
\hline Hingoli & $\mathrm{D}_{4}$ & 106 & $145.20^{\mathrm{bc}} \pm 1.22$ \\
\hline Beed & $\mathrm{D}_{5}$ & 40 & $135.59^{\mathrm{bd}} \pm 1.93$ \\
\hline Colour & & & \\
\hline Dark Red & $\mathrm{C}_{1}$ & 336 & $139.72 \pm 0.80$ \\
\hline Brick Red & $\mathrm{C}_{2}$ & 261 & $140.13 \pm 0.85$ \\
\hline Season & & & \\
\hline Pre-monsoon & $\mathrm{S}_{1}$ & 58 & $140.60^{\mathrm{a}} \pm 1.60$ \\
\hline Monsoon & $\mathrm{S}_{2}$ & 67 & $145.93^{\mathrm{b}} \pm 1.51$ \\
\hline Post-monsoon & $\mathrm{S}_{3}$ & 231 & $139.92^{\mathrm{a}} \pm 0.87$ \\
\hline Summer & $\mathrm{S}_{4}$ & 241 & $133.23^{\mathrm{bc}} \pm 0.82$ \\
\hline
\end{tabular}

Note: Means connected by same superscripts do not differ significantly 
Table.6 Least squares means for GP as affected by block and colour pattern in Red Kandhari cows

\begin{tabular}{|l|l|l|l|}
\hline Sources & Code & $\mathrm{N}$ & Mean GP (Days) \pm SE \\
\hline Population mean & $\mu$ & 597 & $283.49 \pm 0.23$ \\
\hline District & \multicolumn{5}{l|}{} \\
\hline Nanded & $\mathrm{D}_{1}$ & 149 & $283.88 \pm 0.38$ \\
\hline Latur & $\mathrm{D}_{2}$ & 138 & $283.98 \pm 0.39$ \\
\hline Parbhani & $\mathrm{D}_{3}$ & 164 & $283.25 \pm 0.35$ \\
\hline Hingoli & $\mathrm{D}_{4}$ & 106 & $282.93 \pm 0.43$ \\
\hline Beed & $\mathrm{D}_{5}$ & 40 & $283.42 \pm 0.68$ \\
\hline Colour & & & \\
\hline Dark Red & $\mathrm{C}_{1}$ & 336 & $283.60 \pm 0.28$ \\
\hline Brick Red & $\mathrm{C}_{2}$ & 261 & $283.39 \pm 0.30$ \\
\hline Season & & & \\
\hline Pre-monsoon & $\mathrm{S}_{1}$ & 58 & $285.04 \pm 0.57$ \\
\hline Monsoon & $\mathrm{S}_{2}$ & 67 & $280.01 \pm 0.53$ \\
\hline Post-monsoon & $\mathrm{S}_{3}$ & 231 & $283.07 \pm 0.31$ \\
\hline Summer & $\mathrm{S}_{4}$ & 241 & $285.86 \pm 0.29$ \\
\hline
\end{tabular}

Note: Means connected by same superscripts do not differ significantly

\section{Service period (SP)}

It was observed from Table 5 that the overall least square means for SP of Red Kandhari cattle was recorded as $139.92 \pm 0.66$ days. Higher days service period was reported by Dhumal et al., (1989) as 164.72 days and Atharkar (1990) as175.99 \pm 18.03 days in Red Kandhari cattle, respectively and lower days age at first calving was reported by Joshi et al., (2005) as 127.50 \pm 2.03 days in Tharparkar cattle.

\section{Block effect on SP}

The difference observed in the LSMs for SP of Red Kandhari cattle was highly significant due to block effect. The LSM for SP of Red Kandhari cattle in block $\mathrm{D}_{1}, \mathrm{D}_{2}, \mathrm{D}_{3}, \mathrm{D}_{4}$, and $\mathrm{D}_{5}$ were $132.90 \pm 1.07,140.22 \pm 1.10,145.69 \pm$ $1.00,145.20 \pm 1.22$ and $135.59 \pm 1.93$ days, respectively. The DMRT revealed that Red Kandhari cattle maintained at $\mathrm{D}_{3}$ block had highly significant higher SP over other blocks.

\section{Colour pattern effect on SP}

The differences observed in the LSMs for SP of Red Kandhari cattle were non-significant due to colour pattern effect. The LSM for SP of Red Kandhari cattle for colour pattern $\mathrm{C}_{1}$ and $\mathrm{C}_{2}$ were $139.72 \pm 0.80$ and $140.13 \pm 0.85$ days, respectively.

\section{Season effect on SP}

The differences observed in the LSMs for SP of Red Kandhari cattle were highly significant due to season effect. The LSM for SP of Red Kandhari cattle for season $S_{1}, S_{2}, S_{3}$ and $S_{4}$ were $140.60 \pm 1.60,145.93 \pm 1.51,139.92 \pm$ 0.87 and $133.23 \pm 0.82$ days, respectively. The DMRT revealed that Red Kandhari cattle maintained in $\mathrm{S}_{2}$ season had highly significant higher SP over other seasons.

\section{Gestation period (GP)}

It was observed from Table 6 that the overall least square means for GP of Red Kandhari 
cattle was recorded as $283.49 \pm 0.23$ days in the present study which is in agreement with Ghafoor et al., (1980) as 280.44 days and Shelke et al., (1992) as 282.20 days, in Red Kandhari cattle, respectively.

\section{Block effect on GP}

The difference observed in the LSMs for GP of Red Kandhari cattle was non- significant due to block effect. The LSM for GP of Red Kandhari cattle in block $\mathrm{D}_{1}, \mathrm{D}_{2}, \mathrm{D}_{3}, \mathrm{D}_{4}$, and $\mathrm{D}_{5}$ were $283.88 \pm 0.38,283.98 \pm 0.39,283.25$ $\pm 0.35,282.93 \pm 0.43$ and $283.42 \pm 0.68$ days, respectively.

\section{Colour pattern effect on GP}

The differences observed in the LSMs for GP of Red Kandhari cattle were non-significant due to colour pattern effect. The LSM for GP of Red Kandhari cattle for colour pattern $\mathrm{C}_{1}$ and $C_{2}$ were $283.60 \pm 0.28$ and $283.39 \pm 0.30$ days, respectively.

\section{Season effect on GP}

The differences observed in the LSMs for GP of Red Kandhari cattle were non- significant due to season effect. The LSM for GP of Red Kandhari cattle for season $\mathrm{S}_{1}, \mathrm{~S}_{2}, \mathrm{~S}_{3}$ and $\mathrm{S}_{4}$ were $285.04 \pm 0.57,280.01 \pm 0.53,283.07 \pm$ 0.31 and $285.86 \pm 0.29$ days, respectively.

In conclusion the effect of block and season were found highly significant on AP and SP. Hence it is concluded that the management practices, available water and feed resources and climatic condition followed there plays an important role on reproductive performance of Red Kandhari cattle.

\section{Acknowledgment}

I have immense pleasure in expressing my whole hearted sense of gratitude indebtedness towards my Research Guide respected Dr. B. M. Thombre, Associate Dean and Principal, College of Agriculture, Ambajogai, Vasantrao Naik Marathwada Krishi Vidyapeeth, Parbhani, who in the unique way, provided me with constant encouragement, inspiring, scholastic guidance and above all, friendly advice, love and affection offered to me during the course of my study and research.

\section{References}

Atharkar, A.A.1990. Comparative Performance of Production and Reproduction Traits in Red Kandhari and Jersey x Red Kandhari Crossbred Cows. M.V. Sc. Thesis Submitted to MAU, Parbhani (MS).

Azizunnesa, B.C. Sutradhar, M. Hasanuzzaman, O.F. Miazi, M. Aktaruzzaman and Faruk M.O.

2010. Study on the Productive and Reproductive Performances of Red Chittagong Cow at rural areas in Chittagong. Univ. J. Zool. Rajshahi.28 (1): 27 - 31.

Bhutkar, S.S. 2014. Studies on Economic Characteristics of Deoni and Holstein Friesian x Deoni (Holdeo). Ph.D (Agri.) Thesis Submitted to VNMKV, Parbhani (MS).

Chauhan, D.S., Thombre, B.M., Mitkari, K.R., Yadav, K.N. and Bainwad, D.V. 2008. Origin and Historical Background of Red Kandhari Cattle of Maharashtra. National Symposium SOCDAB, Veterinary College, Bangalore: 266.

Dhumal, M.V., Sakhare, P.S and Deshpande,K.S.1989. Factors Affecting Lactation Milk Yield and Lactation Length in Red Kandhari and Crossbred Cows. Indian J.Dairy.Sci.42 (1):102-104.

Ghafoor, M.A., Sakhare, P.G. and Deshpande, K.S. $1980 . \quad$ Note on Breed 
Characteristics of Red Kandhari Cattle. Indian J. Anim. Sci. 50 (8): 652-654.

Gokhale, S. B. 2013. Network Project on Survey Evaluation of Dangi Cattle. Final report submitted to NBAGR, Karnal. Harvey, W.R. 1990. Least Squares Analysis of Data with Unequal Subclass Numbers, Agricultural Research Service, United State, Department of Agriculture, Washington, D.C. Joshi, B. K., Singh, A and Mukherjee, S. 2005. Genetic Improvement of Indigenous Cattle for Milk and Drought: A Review. Indian J Anim Sci. 75 (3): 335-348.

Kramar, C.Y. 1957. Extension of Multiple Range Tests to Group Corrected Adjusted Means. 13: 13-18.

Kulkarni S., R. L. Bhagat, A. B. Pande and S. B. Gokhale, 2013. Management and Physical Features of Tribal Kathani Cattle of Vidarbha Region In Maharatshtra State. Indian J. of Anim. Sci. 83 (6): 625-627. Livestock Census, 2012. 19 th $^{\text {th }}$ Livestock census-2012.www.dahd.nic.in Pundir R.K. and P.K. Singh, 2008. Status, Characteristics and Performance of Red Kandhari Cattle Breed in its Native Tract. Indian J. Anim. Sci. 78 (1): 56-61.

Shelke, B.S., Sakhare, P.G and Deshpande, K.S. 1992. Breeding Efficiency and Milk Producing Ability of Red Kandhari and Jersey x Red Kandhari Halfbred Cows. Indian J. Anim. Sci. 62 (1): 79-80.

Singh G., G.K. Gaur, A.E. Nivsarkar, G.R. Patil \& K.R. Mitkari, 2002. Deoni cattle breed of India. A study on Population Dynamics and Morphometric Characteristics Animal Genetic Resources Information, 232: 35-43.

Vedpathak, C.P., Deshpande, A.D. and Madke, P. K. 2006. Genetic Polymorphism of Haemoglobin in Red Kandhari Cattle. Indian J. Anim. Res. 40 (2): 151-154.

\section{How to cite this article:}

Bainwad, D. V., B. M. Thombre and Narwade, S. G. 2020. Studies on Reproductive Performance of Red Kandhari Cattle in their Breeding Tract of Maharashtra, India. Int.J.Curr.Microbiol.App.Sci. 9(09): 70-78. doi: https://doi.org/10.20546/ijcmas.2020.909.008 